\title{
Early Functional and Radiological Results of Mau Osteotomy for Moderate-Severe Hallux Valgus Deformity
}

\section{Orta-Ciddi Halluks Valgus Deformitelerinde Mau Osteotomisinin Erken Dönem Fonksiyonel Ve Radyolojik Sonuçları}

\author{
Yenel Gürkan Bilgetekin, Sinan Yüksel, Kursat Resat Demir, Orhan Kunu, Halis Atıl Atilla, Önder Ersan \\ Sağlık Bilimleri Üniversitesi Dışkapı Yıldırım Beyazıt Eğitim Ve Araştırma Hastanesi, Ortopedi Ve \\ Travmatoloji Kliniği, Ankara, Türkiye
}

Dergiye Ulaşma Tarihi: Dergiye Kabul Tarihi: Doi: 10.5505/aot.2020.90692

\section{ÖZET}

GÍRIŞ̧ ve AMAÇ: Bu çalışmada orta-ciddi derecede halluks valgus deformitesinde Mau Osteotomisinin erken dönem fonksiyonel ve radyolojik sonuçlarının değerlendirilmesi amaçlandı.

YÖNTEM ve GEREÇLER: Temmuz 2016 - Ocak 2019 tarihleri arasında halluks valgus deformitesi tanısı ile Mau Osteotomisi uygulanan 16 hasta geriye dönük olarak gözden geçirildi. Hastalarımızın ameliyat öncesi ve son takiplerinde klinik bulguları; AOFAS (Amerikan Ortopedi Derneği Ayak-Ayak Bileği Skoru) ve VAS (Visual Analog Skala) ile değerlendirildi. Radyolojik bulgular için her 2 ayak basarak ön-arka ve yan grafiler ile HVA (Halluks valgus açısı), İMA (İntermetatarsal açı) ölçüldü.

BULGULAR: Hastaların 9'u kadın (\%56) 7'si erkek (\%44) olup, ortalama yaş 43,7 idi. Hastaların takip süresi ortalama 18 ay (dağılım: 6-27 ay) idi. Ameliyat sonrası klinik olarak AOFAS ve VAS skorları ameliyat öncesine göre anlamlı olarak düzelmişti $(\mathrm{p}<0.05)$. Ameliyat öncesi radyolojik olarak, HVA $43.75 \pm 7.58$, İMA $16.00 \pm 2.82$ iken; son takipte HVA $22.13 \pm 6.63$, İMA $7.44 \pm 3,38$ olarak düzelmişti $(p<0.05)$. Hastaların $\% 81$ 'inde mükemmel ve iyi sonuç tespit edildi.

TARTIŞMA ve SONUÇ: Sonuç olarak hastalarımızın \%81'inde mükemmel ve iyi sonuç alındı. Halluks valgus deformitesinde Mau Osteotomisi erken dönemde klinik ve radyolojik sonuçlarımıza dayanarak etkin ve güvenilir bir yöntem olabilir.

Anahtar Kelimeler: Halluks valgus, Mau osteotomisi, halluks valgus açısı, intermetatarsal açı, AOFAS

\section{ABSTRACT}

INTRODUCTION: The aim of the present study was to evaluate the early functional and radiological results of Mau osteotomy in the treatment of moderate -severe hallux valgus deformity.

METHODS: A retrospective evaluation was made of 16 patients undergoing Mau osteotomy for treatment of hallux valgus deformity between July 2016 and January 2019. Clinical findings of patients were evaluated in preoperative and the last follow-up visits using the American Orthopaedic Association Foot and Ankle Score (AOFAS) and Visual Analog Scale (VAS). Radiological findings were measured with hallux valgus angle (HVA) and the intermetatarsal angle (IMA) on anteroposterior and lateral standing radiographs of both feet.

RESULTS: 9 (56\%) patients were female and 7 (44\%) male with a mean age of 43.7 years. The mean follow-up period was 18 months (range, 6-27 months). A statistically significant improvement was determined in AOFAS and VAS postoperatively compared to the preoperative values $(\mathrm{p}<0.05)$. Radiologically, the HVA improved from $43.75 \pm 7.58$ preoperatively to $22.13 \pm 6.63$ at the final follow-up examination, and the IMA from $16.00 \pm 2.82$ to $7.44 \pm 3.38(\mathrm{p}<0.05)$. Excellent and good results were obtained in $81 \%$ of the patients.

DISCUSSION AND CONCLUSION: In conclusion, Mau osteotomy can be considered an effective and reliable method in the treatment of hallux valgus deformity, based on the excellent and good clinical and radiological results obtained in $81 \%$ of the current study patients.

Keywords: Hallux valgus, Mau osteotomy, hallux valgus angle, intermetatarsal angle, AOFAS 


\section{INTRODUCTION}

Hallux valgus $(\mathrm{HV})$ is a clinical condition that affects females in particular and when there are clinical symptoms, severely diminishes quality of life. $\mathrm{HV}$ is a common deformity affecting $48 \%$ of the adult population $(1,2)$. As HV deformity is a lateral deviation of the first metatarsophalangeal (MTP) joint, it involves deviation of the first row in several planes. There may also be accompanying deformities such as progressive subluxation of the first MTP joint, metatarsus primus varus, sesamoid subluxation, bunion formation on the metatarsal head and widening of the forefoot $(3,4)$.

For the diagnosis and evaluation of the severity of the disease, the intermetatarsal angle (IMA), distal metatarsal joint angle (DMJA) and hallux valgus angle (HVA) are measured on the standing anterior-posterior (AP) and lateral radiographs. The upper limits are accepted as HVA $15^{\circ}$, IMA $9^{\circ}$ and DMJA $10^{\circ}$. According to these angles and the degree of sesamoid subluxation, the deformity can be classified as mild $\left(\mathrm{HVA} \leq 19^{\circ} ; \quad \mathrm{IMA} \leq 13^{\circ}\right), \quad$ moderate $\left(\mathrm{HVA}=20^{\circ}-40^{\circ} ; \quad \mathrm{IMA}=14^{\circ}-20^{\circ}\right)$ or severe $\left(\mathrm{HVA}>40^{\circ}\right.$; IMA $\left.>20^{\circ}\right)(5)$. When the IMA is $>15^{\circ}$, proximal osteotomy may be necessary. In literature, Scarf or Z osteotomy, Ludloff and Mau osteotomies have been reported to have been carried out for this purpose (6).

In addition to conservative treatments which can provide relief for patients, surgical correction is the most effective treatment in cases in which pain severely restricts quality of life. A large number of surgical techniques have been used in first metatarsal osteotomy, depending on the severity of the deformity, and have been described in literature $(2,7-12)$. The Ludloff osteotomy is a mid-shaft osteotomy oriented from the dorsal-proximal to the plantar-distal. In 1926, Mau described an oblique osteotomy in the sagittal plane from the plantar-proximal extending to the distal-dorsal. Adress for correspondence: e-mai :

Available at www.actaoncologicaturcica.com

Copyright $\odot$ Ankara Onkoloji Hastanesi
The Mau osteotomy has been reported to be reliable, providing strong correction in patients with moderate and severe hallux valgus deformity (13).

The aim of this study was to retrospectively evaluate the early functional and radiological results of patients applied with Mau osteotomy for hallux valgus deformity, the treatment of which remains variable and controversial.

\section{MATERIAL METHOD}

Approval for the study was granted by the Local Ethics Committee. A retrospective evaluation was made of 16 patients undergoing Mau osteotomy between July 2016 and January 2019 for a diagnosis of moderate severity hallux valgus deformity. Hospital records were investigated and patients that meet the inclusion criteria were enrolled in the study. The preoperative and follow up radiographies were obtained from the picture archiving and communication systems (PACS) of the institute (®Extreme PACS \& RIS system; Ankara, Turkey).

The patients applied undergoing osteotomywere evaluated by comparisons of the clinical and radiological results. Inclusion criteria were patients aged 20 to 69 , with moderate to severe HV deformity (determined on $x$-rays; IMA>12 degrees), cooperative, and have the consent for operation and having pain that affecting daily activities, compatible with post-operative rehabilitation program. We excluded the patients that lost to follow up, had prior surgery for HV deformity, patients with body mass index over $25 \mathrm{~kg} / \mathrm{m} 2$ and if they had a major complication related to anesthesia. The age, gender, and affected side were recorded. The degree of postoperative correction in HVA and IMA were recorded together with the functional results according to the Visual Analog Scale (VAS) and American 
Orthopaedic Association Foot and Ankle Score (AOFAS), and complications such as infection, non-union or malalignment. The pre- and postoperative evaluation (angle measurements and clinical evaluation) was performed by an author who was not a member of surgical team and we used patients charts and hospital records to reveal functional outcomes.

All surgeries were performed by the same surgical team and before starting the surgical procedure, $1 \mathrm{gr}$ cefazolin sodium was administered intravenously. The surgery was performed using a pneumatic tourniquet with the patient in the supine position. Entry was made with a dorsomedial incision $3 \mathrm{~cm}$ in length at the proximal of the first metatarsal. After identification of the tarsometatarsal joint, the bunion was excised then an oblique osteotomy was carried out $1 \mathrm{~cm}$ distal of the joint, medially from the plantar-proximal towards the dorsaldistal. Turning the distal fragment $9^{\circ}$, a new level was achieved by obtaining a smaller IMA. Fixation was provided by placing $2 \mathrm{~K}$-wires plantar-dorsal vertical to the osteotomy, and 2 cannulated lag screws of $2.7 \mathrm{~mm}$ or $3.0 \mathrm{~mm}$. After completion of the bone procedures, capsulography and soft tissue procedures were completed. All patients were discharged the day after surgery with a blow-knee-splint and advised not to bear weight. Patients were evaluated 6 weeks after surgery and allowed to bear weight if the union of the osteotomy site is observed. All patients were prescribed for nonsteroidal anti-inflammatory drugs after discharge.

\section{Statistical Analysis}

Data obtained in the study were analysed statistically using IBM SPSS vn.25.0 software (IBM SPSS Statistics for Windows, Version 25.0. Armonk, NY, USA). Preoperative and postoperative HVA, IMA, AOFAS, and VAS values were expressed with mean \pm standard deviation (SD) values. In the comparison of the preoperative and

Adress for correspondence:

e-mail

Available at www.actaoncologicaturcica.com

Copyright $\mathbb{C}$ Ankara Onkoloji Hastanesi postoperative values, the Wilcoxon Signed Rank test was used. A value of $p<0.05$ was accepted as statistically significant.

\section{RESULTS}

The study included 16 adult patients undergoing Mau osteotomy between July 2016 and January 2019 for a diagnosis of HV deformity. The patients comprised $9(56 \%)$ females and 7 (44\%) males with a mean age of $47.3 \pm 18.1$ years (median, 51.5 years; range, 21-69 years). The mean follow-up period was

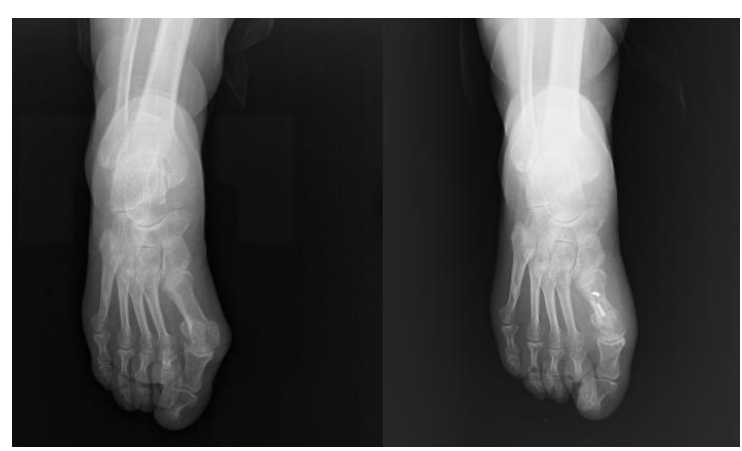

Figure 1. Preoperative and postoperative final radiographs of a right foot applied with Mau osteotomy.

18 months (range, 6-27 months). The HV deformity wasat right side in 8 cases and left side in 8 cases. The radiological measurements were determined tobe HVA43.75 \pm 7.58 preoperatively and $22.13 \pm 6.63$ at the final follow-up examination, and IMA was $16.00 \pm$ 2.82 preoperatively and $7.44 \pm 3.38$ at the final follow-up examination $(\mathrm{p}<0.05)$ (Figure 1). VAS was determined to be $8.63 \pm 1.14$ preoperatively and $1.25 \pm 0.85$ at the final follow-up examination and AOFAS was 33.69 \pm 14.37 and $84.38 \pm 6.67$, respectively $(\mathrm{p}<0.05$, $\mathrm{p}<0.05$ ) (Table 1). 
In 2 patients with hammer deformity of

surgical techniques used in moderate and severe

Table 1. Preoperative and postoperativeHVA, IMA, AOFAS, and VAS values of the patients

\begin{tabular}{lccc}
\hline & $\begin{array}{c}\text { Preoperative } \\
\text { Mean } \pm \text { SD }\end{array}$ & $\begin{array}{c}\text { Postoperative } \\
\text { Mean } \pm \text { SD }\end{array}$ & $\mathbf{P}^{*}$ \\
Median (minimum- maximum) & Median (minimum- maximum) & \\
HVA & $43.75 \pm 7.58$ & $22.13 \pm 6.63$ & $<0.0001$ \\
IMA & $43(30-59)$ & $20.5(13-33)$ & $<0.0001$ \\
& $16.00 \pm 2.82$ & $7.44 \pm 3,38$ & $<0.0001$ \\
VAS & $16(12-23)$ & $7.5(3-14)$ & $<0.0001$ \\
& $8.63 \pm 1.14$ & $1.25 \pm 0.85$ &
\end{tabular}

*Wilcoxon Signed Rank test

the 2nd toe in addition to HV deformity, toe arthrodesis with $\mathrm{K}$-wire was conducted in the same session. In 1 of these patients, plate-screw revision was made because of loss of reduction and fixation related to inappropriate weightbearing during the follow-up period.

\section{DISCUSSION}

Hallux valgus deformity is a widespread deformity affecting approximately $48 \%$ of the adult population and is one of the most frequently occurring complaints of patients presenting to orthopaedic polyclinics $(1,2)$. It is one of the most important differential diagnoses in patients presenting with foot pain $(14,15)$.

Of the many treatment methods described for $\mathrm{HV}$ deformity, metatarsal osteotomy performed with the appropriate technique for appropriate indications is a method with pleasing results, which improves the quality of life of patients. Proximal Chevron and Ludloff osteotomies are amongst these methods $(2,13,14)$. The Mau osteotomy has been reported to be more successful than these osteotomies with respect to stability $(1,15)$. The aim of this study was to evaluate the efficacy of the Mau osteotomy as one of the
HV deformities.

There are few studies in literature that have compared the amount of correction in Mau osteotomy with that of other proximal metatarsal osteotomies $(2,13,15)$. In a study by Tanujanet al. (2), the HVA and IMA were reported to be39 ${ }^{\circ}$ (range, 22-58) and $15^{\circ}$ (range, 13-21) respectively, preoperatively, and $15^{\circ}$ (range, -2-36) and $9{ }^{\circ}$ (range, 0-14) postoperatively. Glover et al. (13)reported that the preoperative mean HVA and IMA values of $31.3^{\circ}$ and $16.6^{\circ}$ respectively, improved to $13.00^{\circ} \pm 7.15^{\circ}$ and $9.80^{\circ} \pm 2.43^{\circ}$ respectively, postoperatively. In the current study, the radiological values were determined tobe HVA43.75 \pm 7.58 preoperatively and $22.13 \pm$ 6.63 at the final follow-up examination, and IMA $16.00 \pm 2.82$ preoperatively and $7.44 \pm$ 3.38 at the final follow-up examination $(\mathrm{p}<0.05)$.

In the study of Tanujanet al(2), the mean AOFAS was reported to be 47 (range, 3462) preoperatively and 93 (range, 69-100) postoperatively. In a study by Arcuriet al(16), the preoperative AOFAS was mean $25.5 \pm 16.7$ and this increased to $95.4 \pm 5.7$ postoperatively. In the current study, the preoperative AOFAS of 
$33.69 \pm 14.37$ increased to $84.38 \pm 6.67$ at the final follow-up examination $(\mathrm{p}<0.05)$.

In the study of Glover et al(13), complications were recorded as deformity recurrence in 3 patients, open non-union in 1 , dorsal cortical non-union in 8 , insufficient correction in 5 , and fracture in 1 . In the current study, fracture was determined in 1 patient, for which revision surgery was performed with plate and screws.

The main limitation of our study was the lack of a control group and the retrospective manner. But considering the major differences between pre-operative and post-operative findings of patients undergoing Mau osteotomy, it is proper to conclude the radiological and functional outcomes of this surgical method.

\section{REFERENCES}

1. Neese DJ, Zelent ME. The Modified Mau-Reverdin Double Osteotomy for Correction of Hallux Valgus: A Retrospective Study. JFoot Ankle Surg. 2009;48(1):2229.

2. Thangarajah T, Ahmed U, Malik S, et al. The early functional outcome of mau osteotomy for the correction of moderate-severe hallux valgus. Orthop Rev. 2013;5(4):e37.

3. Okuda R, Kinoshita M, Morikawa J, et al. Distal soft tissue procedure and proximal metatarsal osteotomy in hallux valgus. Clin Orthop Relat Res. 2000;(379):209-17.

4. Doğan A, Üzümcügil O, Akman YE. Halluks Valgus. TOTBID. 2007;(2):88-94.

5. Robinson AHN, Limbers JP. Modern concepts in the treatment of hallux valgus. J Bone Joint Surg $\mathrm{Br}$. 2005;87(8):1038-45.

6. Bar-David T, Greenberg PM. Retrospective analysis of the Mau osteotomy and effect of a fibular sesamoidectomy. JFoot Ankle Surg. 1998;37(3):212-16.

7. Cedell CA, Aström M. Proximal metatarsal osteotomy in hallux valgus. Acta Orthop. 1982;53(6):1013-18.

8. Young KW, Lee HS, Park SC. Modified Proximal Scarf Osteotomy for Hallux Valgus. ClinicOrthop Surg. 2018;10(4):479-83.

9. Limbird TJ, DaSilva RM, Green NE. Osteotomy of the first metatarsal base for metatarsus primus varus. Foot Ankle. 1989;9(4):158-62.

10. Mann RA, Rudicel S, Graves SC. Repair of hallux valgus with a distal soft-tissue procedure and proximal metatarsal osteotomy. A long-term follow-up. Journal Bone Joint Surg Am. 1992;74(1):124-29.

Adress for correspondence

e-mail:

Available at www.actaoncologicaturcica.com

Copyright $\odot$ Ankara Onkoloji Hastanesi
Future studies should try to reveal the advantages or disadvantages of Mau osteotomy with a prospective design and control groups.

\section{Conclusion}

In conclusion, the results of this study demonstrated that excellent and good results were obtained in $81 \%$ of the patients. Therefore, on the basis of these early clinical and radiological results, Mau osteotomy can be considered an effective and reliable method in the treatment of hallux valgus deformity.

Conflict of Interests Authors state no conflict of interests

Funding No funding available for this study

11. Wanivenhaus AH, Feldner-Busztin H. Basal osteotomy of the first metatarsal for the correction of metatarsus primus varus associated with hallux valgus. Foot Ankle. 1988;8(6):337-43.

12. Akkaya M. Clinical Outcomes of Proximal OpeningWedge Osteotomy and Distal Chevron Osteotomy in the Treatment of Moderate Hallux Valgus Deformity. JMSCR. 2019;7(2):753-60.

13. Glover JP, Hyer CF, Berlet GC, et al. Early Results of the Mau Osteotomy for Correction of Moderate to Severe Hallux Valgus: A Review of 24 Cases. J Foot Ankle Surg. 2008;47(3):237-42.

14. Eken F, Özcan Ç, Kurtulmus T, et al. Scarf osteotomisi ileri seviye halluks valguslarda Turan ve Distal chevron osteotomileri kadar etkili midir? Acta Medica Alanya. 2019;3(2):140-45.

15. Acevedo JI, Sammarco VJ, Boucher HR, et al. Mechanical comparison of cyclic loading in five different first metatarsal shaft osteotomies. Foot Ankle Int. 2002;23(8):711-16.

16. Arcuri N, Bar-David T, Pollack S. The Mau-Reverdin Osteotomy: A Short-Term Retrospective Analysis. J Foot Ankle Surg. 2016;55(4):794-98. 